\title{
Problems with estimation and interpretation of oceanic heat transport - conceptual remarks for the case of Fram Strait in the Arctic Ocean
}

\author{
U. Schauer and A. Beszczynska-Möller \\ Alfred Wegener Institute for Polar and Marine Research, Bremerhaven, Germany
}

Received: 29 April 2009 - Published in Ocean Sci. Discuss.: 18 May 2009

Revised: 12 October 2009 - Accepted: 17 October 2009 - Published: 3 November 2009

\begin{abstract}
While the concept of oceanic heat transport - or rather heat transport divergence - is well known, it is sometimes applied inaccurately. Often so-called "heat transports" are computed across a partial section which means that the volume flow through such a section is not zero. In this case the "heat transports" depend entirely on the choice of the temperature scale. The consequences of such arbitrariness are demonstrated with a simple calculation exercise for the passages to the Arctic Ocean. To circumvent the arising difficulties for the Fram Strait in the Arctic we propose a stream tube concept to define a net zero volume flow section which can, with coarse assumptions, be used to determine oceanic heat transport by the portion of Atlantic water flow that passes through Fram Strait. Weaknesses of this approach and consequences for observational strategies are discussed.
\end{abstract}

\section{Introduction}

Oceanic heat transport is a crucial component in the global climate system because it is partly responsible for compensating the global meridional radiation imbalance (e.g. Hall and Bryden, 1982). This holds also for the northern high latitudes although here oceanic heat transport is small compared to that of mid latitudes. Yet in recent years, the role of the oceanic heat import from sub-arctic oceans is debated in the context of the sea ice reduction.

The Arctic Mediterranean has several openings to the world ocean which impedes straightforward computation of the heat transport from temperature and velocity measurements. Nevertheless, the last decade shows a wealth of publications from which a misconception of the principle for advective heat transport - not only for northern



Correspondence to: U. Schauer (ursula.schauer@awi.de) latitudes - is evident (among many others: Schauer et al., 2004; Maslowski et al., 2004; Cuny et al., 2005). This makes it worthwhile to bring to mind once more the basic concepts which have been described in the oceanographic literature for more than thirty years (Montgomery, 1974; Hall and Bryden, 1982) and to illustrate the consequences of their violation in Sect. 2. An approach to estimate heat transport of Atlantic Water flow through Fram Strait from observations is presented in Sect. 3 and the uncertainties associated with such an approach are analysed in Sect. 4. In Sect. 5 we discuss essential observational conditions for heat transport estimates. For clarity, we will use the term heat transport without quotes for correctly derived heat transports, while we will write the term in quotes if it is derived from a wrong concept.

\section{Concept of oceanic heat transport and problems arising from its misconception}

"Heat carried by 1 ton of water at $30^{\circ} \mathrm{C}$ cannot be compared with the heat carried by 30 tons of water at $1^{\circ} \mathrm{C} . "$ (Montgomery, 1974)

The physical idea behind oceanic advective heat transport is related to the temperature transport divergence. It can be derived from the heat (more precisely: internal energy) conservation equation, which for an ocean water parcel, under the simplification of incompressibility, can be written as

$\frac{\partial T}{\partial t}+\boldsymbol{v} \cdot \nabla T=-\frac{1}{\rho c_{p}} \nabla \cdot \boldsymbol{f}$,

where $T$ is the potential temperature referred to atmospheric pressure, $c_{p}$ is the specific heat at atmospheric pressure and $\rho$ is the density. $\boldsymbol{v}$ is the three-dimensional velocity vector, and $\boldsymbol{f}$ combines turbulent and conductive heat flux densities.

Since Eq. (1) deals with temperature derivatives only, $T$ can be expressed either in Celsius scale or in absolute scale or it can be referred to any constant reference temperature

Published by Copernicus Publications on behalf of the European Geosciences Union. 
$T_{\text {ref. Here, }} \mathrm{c}_{p}$ and $\rho$ are considered constant, while $\boldsymbol{v}, \boldsymbol{f}$ and $T$ may vary with time, $t$, and space. Equation (1) may be integrated over a full depth ocean volume, Vol. Under the assumption of incompressibility $\boldsymbol{v}$ has zero divergence and Gauss' theorem can be applied so that

$$
\begin{aligned}
& \oint d s \int_{0}^{d(s)} v_{\perp}(s, z, t) \cdot\left(T(s, z, t)-T_{r e f}\right) d z= \\
& -\iiint_{\text {Vol }} d x d y d z \frac{\partial\left(T-T_{\text {ref }}\right)}{\partial t}-\frac{F_{\text {ocsurf }}(t)}{c_{p} \rho} .
\end{aligned}
$$

$v_{\perp}$ is the velocity component perpendicular to the open ocean boundary confining the volume. The integral on the left-hand side is taken over the full depth, $d$, along the entire ocean boundary of which ds is a length element. $F_{\text {ocsurf }}$ is the heat flux through the entire interface between ocean and atmosphere; diffusive and turbulent fluxes, including those caused by unresolved mesoscale eddies, across the lateral boundaries are considered negligible here.

Equation (2) expresses the simple fact that currents across the boundary of any ocean segment change the heat content by replacing a certain amount of water of a particular temperature by the same amount of water with another temperature. Such an exchange can be achieved by ocean currents of any scale, by basin-wide gyres or overturning cells as well as by eddies. At stationary conditions the heat gain or loss through currents will be balanced by the heat exchange with the atmosphere, $F_{\text {ocsurf. }}$ At variable conditions, in addition a change of the heat content of the ocean segment with time is possible.

This concept sounds (and probably is) trivial. However, computation of heat transport by evaluating observations or model results are sometimes far from straightforward. This is partly due to the complexity of ocean currents and the resulting necessity to determine both velocity and temperature along the boundary at a sufficiently high spatial resolution.

A second problem often arises from the formulation of the advective heat transport term itself. It is extremely tempting to integrate only over a partial cross-section instead over the closed boundary. It is sometimes argued that such "heat transports" can also be used themselves e.g. for comparing different cross-section parts (Karcher et al., 2003) or to rate temporal changes through a particular partial cross-section (Schauer et al., 2004). It is also suggested that certain reference temperatures such as the volume average temperature (Lee et al., 2004; Kim et al., 2004) are well suited to derive heat transport. However, any arbitrary reference temperature makes a "heat transport" across a partial section arbitrary and provides equally arbitrary results for comparisons as is illustrated below.

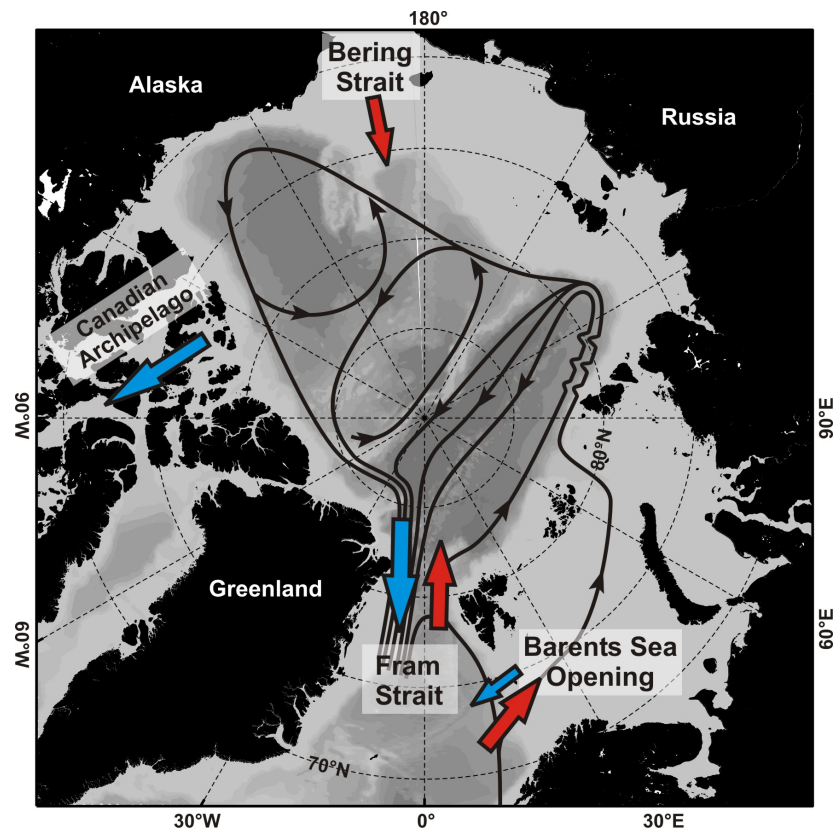

Fig. 1. Map of the Arctic Ocean with a qualitative sketch of the flows through passages to the Atlantic and Pacific (see Table 1) and the circulation scheme of Atlantic-derived water (after Fig. 9 in Rudels et al., 1994).

The Arctic Ocean has four passages to sub-arctic oceans: the Bering Strait, the Canadian Archipelago, the Fram Strait and the Barents Sea Opening (Fig. 1). None of these straits accommodates a balanced volume flow. Yet, in many publications the involved restraints have been ignored and "heat transports" across these straits were presented (Schauer et al., 2004; Walczowski et al., 2005; Karcher et al., 2003).

A simple exercise may illustrate the arbitrariness of such attempts. Table 1 shows results for the heat balance of a very simplified Arctic Ocean to and from which ocean currents transport water with temperatures given in different temperature scales, Celsius and absolute. The net production of Arctic sea ice, approximately $0.1 \mathrm{~Sv}$ (Vinje et al., 2001) exported through Fram Strait, corresponds to a latent heat transport of 33 TW. This number is obviously independent of the temperature scale.

Also the total heat gain of the Arctic Ocean is independent of the temperature scale because volume transports are balanced. The "heat transports" of individual flow branches, however, differ considerably between the absolute and the Celsius scale and even change their sign. Indeed, with both scales the "heat transport" associated with the Fram Strait inflow is larger than that with the Barents Sea inflow, however, the heat transport ratio between the two branches depends on the reference temperature. While the Fram Strait inflow heat transport is twice as large as that of the Barents Sea inflow when using the Celsius scale it is more than three times as large with the absolute scale. 
Table 1. Heat balance of a simplified Arctic Ocean (the numbers are not meant to describe the real Arctic Ocean). In- and outflow (voltransp) of water with temperatures, Temp, through the various openings cause temperature transports that sum up to heat transport to the Arctic Ocean. For the left rows the Celsius scale was used, for the right rows the calculation was done with absolute temperatures. The latent heat of freezing is independent of the temperature scale and is additive to both columns. Before freezing, the respective $0.1 \mathrm{~Sv}$ of water have to be cooled to the freezing point. ${ }^{*}$ ) The volume transport attributed to sea ice is considered only once for the summation.

\begin{tabular}{|c|c|c|c|c|c|}
\hline Tref & $\begin{array}{r}\text { Temp } \\
\left({ }^{\circ} \mathrm{C}\right) \\
\\
0\end{array}$ & $\begin{array}{r}\text { Voltransp } \\
(\mathrm{Sv})\end{array}$ & $\begin{array}{r}\text { "Heat } \\
\text { transport" } \\
(\mathrm{TW})\end{array}$ & $\begin{array}{r}\text { Temp } \\
\left({ }^{\circ} \mathrm{C}\right) \\
-273\end{array}$ & $\begin{array}{r}\text { "Heat } \\
\text { transport" } \\
(\mathrm{TW})\end{array}$ \\
\hline Bering Strait & 2 & 1 & 8 & 275 & 1100 \\
\hline Can Archip & -0.7 & -1 & 2.8 & 272.3 & -1089.2 \\
\hline Barents Sea in & 5 & 2.5 & 50 & 278 & 2780 \\
\hline Barents Sea out & 2 & -0.5 & -4 & 275 & -550 \\
\hline Fram Strait in & 3 & 9 & 108 & 276 & 9936 \\
\hline Fram Strait out & -1 & -10.9 & 43.6 & 272 & -11859.2 \\
\hline $\begin{array}{l}\text { Fram Strait out } \\
\text { (cooled to } \\
\text { freezing temp) }\end{array}$ & -2 & -0.1 & 0.8 & 271 & -108.4 \\
\hline \multirow{2}{*}{$\begin{array}{l}\text { Fram Strait out } \\
\text { (as sea ice*) }\end{array}$} & & -0.1 & 33 & & 33 \\
\hline & & $\begin{array}{l}\mathrm{Net} \\
(\mathrm{Sv})\end{array}$ & $\begin{array}{r}\text { Heat } \\
\text { transport } \\
(\mathrm{TW})\end{array}$ & & $\begin{array}{r}\text { Heat } \\
\text { transport } \\
(\mathrm{TW})\end{array}$ \\
\hline $\begin{array}{l}\text { Arctic Ocean } \\
\text { total }\end{array}$ & & 0 & 242.2 & & 242.2 \\
\hline
\end{tabular}

The effects are similar when comparing temporal changes (Montgomery, 1974). Heat transport to the Arctic Ocean can change because of varying temperature difference between inflow and outflow and because of varying flow strengths. Again, consideration of changes of an individual flow branch leads to arbitrary results. In the example given in Table 2 the inflow through Fram Strait is increased by $1 \mathrm{~Sv}$ $\left(1 \mathrm{~Sv}=10^{6} \mathrm{~m}^{3} / \mathrm{s}\right)$ with respect to the example of Table 1 . To keep the volume of the Arctic Ocean constant we assume that the Fram Strait outflow compensates the change and increases as well. Since both Fram Strait and Barents Sea inflow exit the Arctic through Fram Strait (see Sect. 3) we cannot tell a priori which water contributes to the outflow increase. The according "heat transport" increase in the Fram Strait inflow gives additional $12 \mathrm{TW}$ with the Celsius scale and additional $1104 \mathrm{TW}$ with the absolute scale. The true additional heat transport for the Arctic Ocean is, however, $16 \mathrm{TW}$, independent of the temperature scale.

\section{A stream tube concept for the West Spitsbergen Current}

The above examples underline that principally all Arctic Ocean openings have to be addressed simultaneously, thereby including the flows of both water and sea ice, to accomplish the requirements of Eqs. (1) and (2) and to obtain oceanic heat transport variability. Since the volume flux through, e.g. Fram Strait is not balanced "heat transport through Fram Strait" is an ill-defined term.

The only way to elude this difficulty is if we can use constraints provided through the Arctic Ocean internal circulation. For example, basically all warm Pacific Water entering through the shallow Bering Strait has been shown to cool to freezing temperature before it exits the Arctic Ocean which suggests that the heat transport can be derived from the inflow referred to freezing temperature (Woodgate et al., 2006). However, because latent heat of fusion is large the heat transport through the net export of sea ice cannot be neglected. If e.g. four percent of the $1 \mathrm{~Sv}$ inflow through Bering Strait left the Arctic as ice, the heat transport would have been about twice the numbers given by Woodgate et al. (2006).

Yet, for the WSC water returning to Fram Strait even the assumption of constant outflow temperature is not valid. Therefore, only if we can identify sections in Fram Strait with compensating in- and outflow, i.e. if we can regard the flow in a stream tube, we can derive the heat transport provided through this pair of partial sections.

To define a stream tube, we assume here that all of the Atlantic Water that is carried to the Arctic Ocean in the West Spitsbergen Current (WSC) through Fram Strait also leaves the Arctic Ocean through Fram Strait. ${ }^{1}$ In the Arctic Ocean, part of the Fram Strait Atlantic Water follows the shelf edge and travels around all basins, part of it returns along the mid ocean ridges and some of it returns after only a short loop in the northern Fram Strait (Fig. 1). The travel within the various loops lasts between months and decades. Warm water anomalies that have entered the Arctic Ocean with the WSC in the nineties are reported to spread in the Eurasian Basin (Karcher et al., 2003; Polyakov et al., 2005) and it is unclear which part of the associated additional heat is released to the

\footnotetext{
${ }^{1}$ Water from the WSC propagating anticyclonically along the shelf edge into the Nansen Basin might flow on the shelf and return to the northern and then western Barents Sea. This is probably only a small fraction of the water within the upper $150 \mathrm{~m}$ since much of the water entering the shelf through a canyon returns in a cyclonic loop to the shelf edge. A small fraction might however circulate anticyclonically around Svalbard. The flow through the $50 \mathrm{~m}$ deep Bering Strait is of the order $1 \mathrm{~Sv}$ to the north and there are no reports about Fram Strait water travelling southward to the Pacific. The Canadian Archipelago (sill depth $160 \mathrm{~m}$ ) is the main gateway for the exit of Pacific Water (Steele et al., 2004) and for a fraction of Barents Sea water (Rudels et al., 2004). The net flow is between 2 and 3 Sv (Cuny et al., 2005). Any fraction from Fram Strait is probably small.
} 
Table 2. As in Table 1. The rows "Change to Table 1" give the "heat transport" difference between the rows in Table 2 and the respective rows in Table 1. Changed parameters are bold.

\begin{tabular}{|c|c|c|c|c|c|c|c|}
\hline Tref & $\begin{array}{r}\text { Temp } \\
\left({ }^{\circ} \mathrm{C}\right) \\
\\
0\end{array}$ & $\begin{array}{r}\text { Voltransp } \\
(\mathrm{Sv})\end{array}$ & $\begin{array}{r}\text { "Heat } \\
\text { transport" } \\
(\mathrm{TW})\end{array}$ & $\begin{array}{r}\text { Change to } \\
\text { Table } 1 \\
(\mathrm{TW})\end{array}$ & $\begin{array}{l}\text { Temp } \\
\left({ }^{\circ} \mathrm{C}\right) \\
-273\end{array}$ & $\begin{array}{r}\text { "Heat } \\
\text { transport" } \\
(\mathrm{TW})\end{array}$ & $\begin{array}{r}\text { Change to } \\
\text { Table } 1 \\
\text { (TW) }\end{array}$ \\
\hline Bering Strait & 2 & 1 & 8 & & 275 & 1100 & \\
\hline Can Archip & -0.7 & -1 & 2.8 & & 272.3 & -1089 & \\
\hline Barents Sea in & 5 & 2.5 & 50 & & 278 & 2780 & \\
\hline Barents Sea out & 2 & -0.5 & -4 & & 275 & -550 & \\
\hline Fram Strait in & 3 & 10 & 120 & 12 & 276 & 11040 & 1104 \\
\hline Fram Strait out & -1 & -11.9 & 47.6 & 4 & 272 & -12947.2 & -1088 \\
\hline $\begin{array}{l}\text { Fram Strait out } \\
\text { (cooled to } \\
\text { freezing temp) }\end{array}$ & -2 & -0.1 & 0.8 & & 271 & -108.4 & \\
\hline \multirow{2}{*}{$\begin{array}{l}\text { Fram Strait out } \\
\text { (as sea ice*) }\end{array}$} & & -0.1 & 33 & & & 33 & \\
\hline & & $\begin{array}{l}\text { Net } \\
(\mathrm{Sv})\end{array}$ & $\begin{array}{r}\text { Heat } \\
\text { transport } \\
(\mathrm{TW})\end{array}$ & & & $\begin{array}{r}\text { Heat } \\
\text { transport } \\
(\mathrm{TW})\end{array}$ & \\
\hline $\begin{array}{l}\text { Arctic Ocean } \\
\text { total }\end{array}$ & & 0 & 258.2 & 16 & & 258.2 & 16 \\
\hline
\end{tabular}

surface and which part leaves the Arctic Ocean after several months, years or decades. However, assuming that the water finally returns to Fram Strait we can consider the looping tubes as a closed volume.

This should enable us to use observations of velocity and temperature that were obtained with moored instruments in Fram Strait and compute the heat transport provided by the WSC by adding the transports of in- and outflow (Schauer et al., 2008). The mooring array is maintained since 1997 up to now and covers the entire cross section of Fram Strait between the shelf edges (Fig. 2). Velocity and temperature values are measured once per hour; data processing and averaging details are given in Fahrbach et al. (2001). Time series of "heat transport" can be derived from the interpolated fields of temperature and cross-section component of the velocity (Schauer et al., 2004). Since the southward volume flow is larger than the northward flow, the critical point is how to identify which of the southward flow is returning WSC water and which water stems from other openings like the Barents Sea Opening or the Bering Strait.

We assume that owing to continuity, water from any loop of the returning WSC will flow southward immediately west of the WSC. There is no indication that the Barents Sea branch that enters the central Arctic Ocean through the St. Anna Trough crosses any of the WSC-derived loops. Rudels et al. (1994) and Schauer et al. (2002a) showed that the Barents Sea water displaces the Fram Strait branch off the slope at the confluence of the two branches in the northern Kara Sea and that further downstream the two branches run parallel with the Barents sea branch at the slope side and the Fram Strait branch flowing at the basin side (Fig. 1). If this pattern continues along the entire Artic Ocean rim and ridges all West Spitsbergen Current-derived outflow through Fram Strait would take place immediately west of the inflow and the Barents Sea water would exit the Arctic to the west of that forming another stream tube between the Barents Sea Opening and the Fram Strait.

Because of this circulation we suggest that southward flow in the central part of Fram Strait originates from the WSC. However, we have to find out how far to the west this return flow of WSC water reaches, i.e. to what extent the East Greenland Current is constituted from WSC water and to what extent from other sources. We assume that the warmest water stems from the WSC.

To avoid volume flux uncertainties that arise from poorly resolved deep-water fluxes we limit our computations to the upper and intermediate waters. Deep water (deeper than ca. $500 \mathrm{~m}$ ) entering the Arctic is not known to up-well there and therefore has to return as deep flow through Fram Strait because all other straits are too shallow. Furthermore it must return at the same temperature; it might be mixed with other deep water, e.g. from the Barents Sea Opening, which would be at similar temperatures. We use a temperature $T_{\mathrm{DI}}$ as a limiting criterion for the upper warm northward flowing WSC water included in the heat transport computation. The choice of $T_{\mathrm{DI}}$ bears some arbitrariness which is discussed below. 

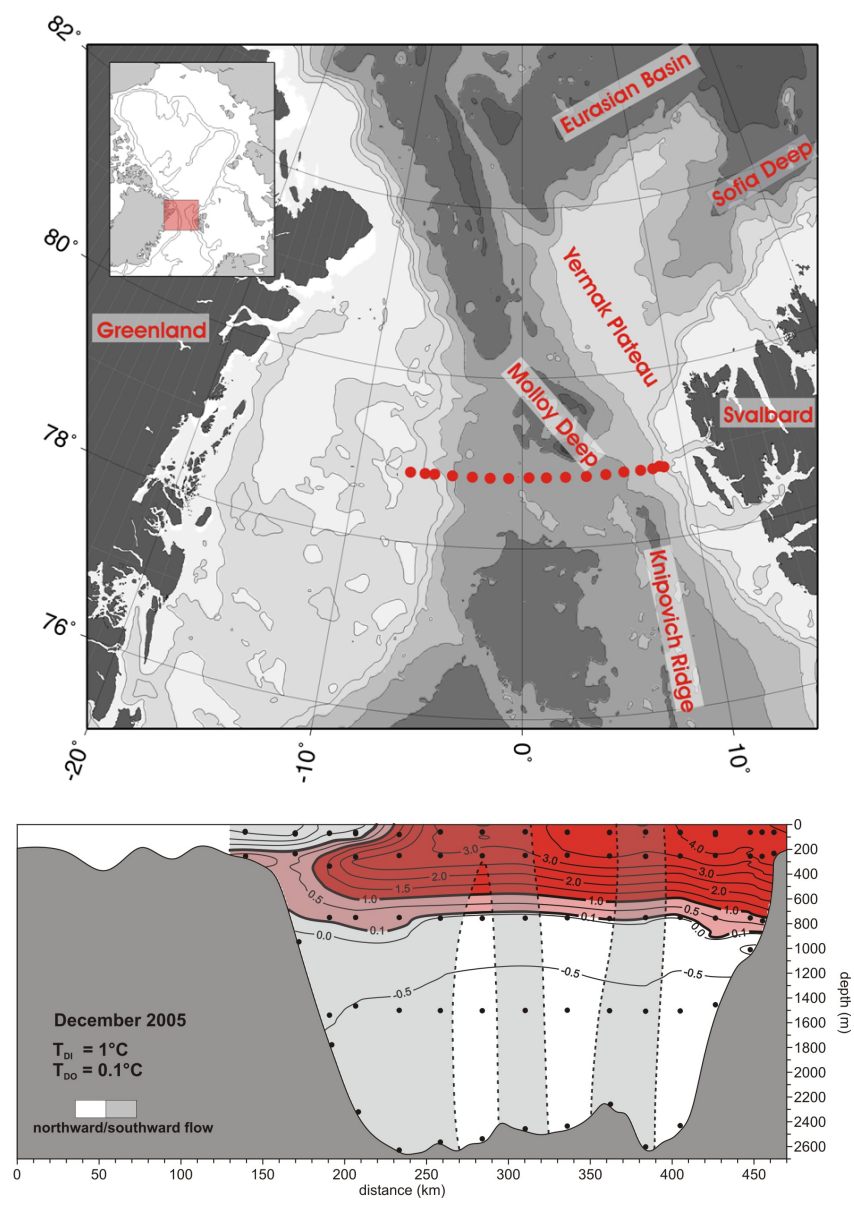

Fig. 2. Upper panel: Location of the mooring array in Fram Strait (red dots) maintained from 1997 until 2008, numbers of moorings varying between 12 and 17. Lower panel: Average temperature and cross-section flow direction of December 2005. At each dot velocity and temperature was measured. Lines with numbers denote isotherms in ${ }^{\circ} \mathrm{C}$. Dark red marks the range which is warmer than $T_{\mathrm{DI}}=1^{\circ} \mathrm{C}$ (see text for explanation), light red marks the additional range of water warmer than $T_{\mathrm{DO}}$ which was $0.1^{\circ} \mathrm{C}$ for this month. Gray shading indicates southward flow; no gray shading indicates northward flow. Note that our integration was done over areas in dark red without gray shading for northward flow and over dark red plus light red areas with gray shading for southward flow to give zero net transport.

Here we will consider results from using $T_{\mathrm{DI}}=1^{\circ} \mathrm{C}$. With the exception of the front around the $1^{\circ} \mathrm{C}$-isotherm outcrop in the western Fram Strait the depth of $1^{\circ} \mathrm{C}$ is below $500 \mathrm{~m}$. This holds particularly for all northward flowing water (Fig. 2).

The transport of upper layer water warmer than $1^{\circ} \mathrm{C}$ (Fig. 2) is integrated over the entire cross section. The net volume flux can be positive, zero or negative. With zero net volume flux we obtain immediately the heat flux of WSC to the Arctic Ocean by integrating the according temperature fluxes over the respective section. In the case that the net volume flux of water warmer than $1^{\circ} \mathrm{C}$ was northward, obviously some WSC water has been cooled to temperatures below $1^{\circ} \mathrm{C}$ before returning. In this case we have increased the integration area over southward flowing water by incrementally increasing the limiting temperature, $T_{\mathrm{DO}}$, including water colder than $1^{\circ} \mathrm{C}$ until the net flux is zero. With increments of $0.1 \mathrm{~K}$ we reach deviations from zero volume fluxes of less than $\pm 0.4 \mathrm{~Sv}$.

A net southward volume flux would mean that there is water warmer than $1^{\circ} \mathrm{C}$ flowing southward that does not originate from the WSC. This is very unlikely according to oceanographic knowledge. Water that entered through the very shallow Bering Strait will have been cooled to near freezing before it ever reaches Fram Strait after crossing the entire Arctic. Barents Sea water loses much of its heat on the shelf so that it is densified and sinks to intermediate depths when entering the Eurasian Basin in the northern Kara Sea. According to observations taken in the early and mid-1990s (Schauer et al., 2002b) all Atlantic water that leaves the eastern Barents Sea is colder than $0^{\circ} \mathrm{C}$. This might have been different in years thereafter. However, if Barents Sea water entered the central Arctic warmer than at $0^{\circ} \mathrm{C}$ it would be lighter than Fram Strait water and therefore closer to the surface. In this case it is exposed to Arctic surface influences more than WSC water because it travels along the shelf edge and is more likely to upwell than Fram Strait waters. Furthermore it has the longest pathway. Therefore, we assume cases of net southward volume flux of water warmer than $1^{\circ} \mathrm{C}$ in Fram Strait to be caused by a respective error in the velocity field due to insufficient spatial resolution so that we cannot estimate a heat flux in that period.

The result for this approach of computing heat flux to the Arctic through WSC water is given in Fig. 3. For $T_{\mathrm{DI}}=1^{\circ} \mathrm{C}$, the lower temperature limit for the outflow, $T_{\mathrm{DO}}$, chosen to obtain zero monthly net volume flux, varies between -0.7 and $0.7^{\circ} \mathrm{C}$ except of one month with $-1.6^{\circ} \mathrm{C}$. The increase of the annual running mean in the first two years is from $26 \mathrm{TW}$ to $36 \mathrm{TW}$; note that using the same data but a wrong method, Schauer et al. (2004) stated an increase more than twice as high, from 16 to $41 \mathrm{TW}$. The annual mean heat flux increased from $26 \mathrm{TW}$ in 1998 to $50 \mathrm{TW}$ in 2004 . While the temperatures of the WSC water continued to rise to a record high in 2006 (Fig. 4) the associated heat flux decreased again to less than $35 \mathrm{TW}$ (Fig. 3) because very warm water returned in that same year to the Greenland Sea, either because the immediate return flow in the Fram Strait region was strong or because water from earlier warm pulses that had entered the Eurasian Basin now reached the Fram Strait. 

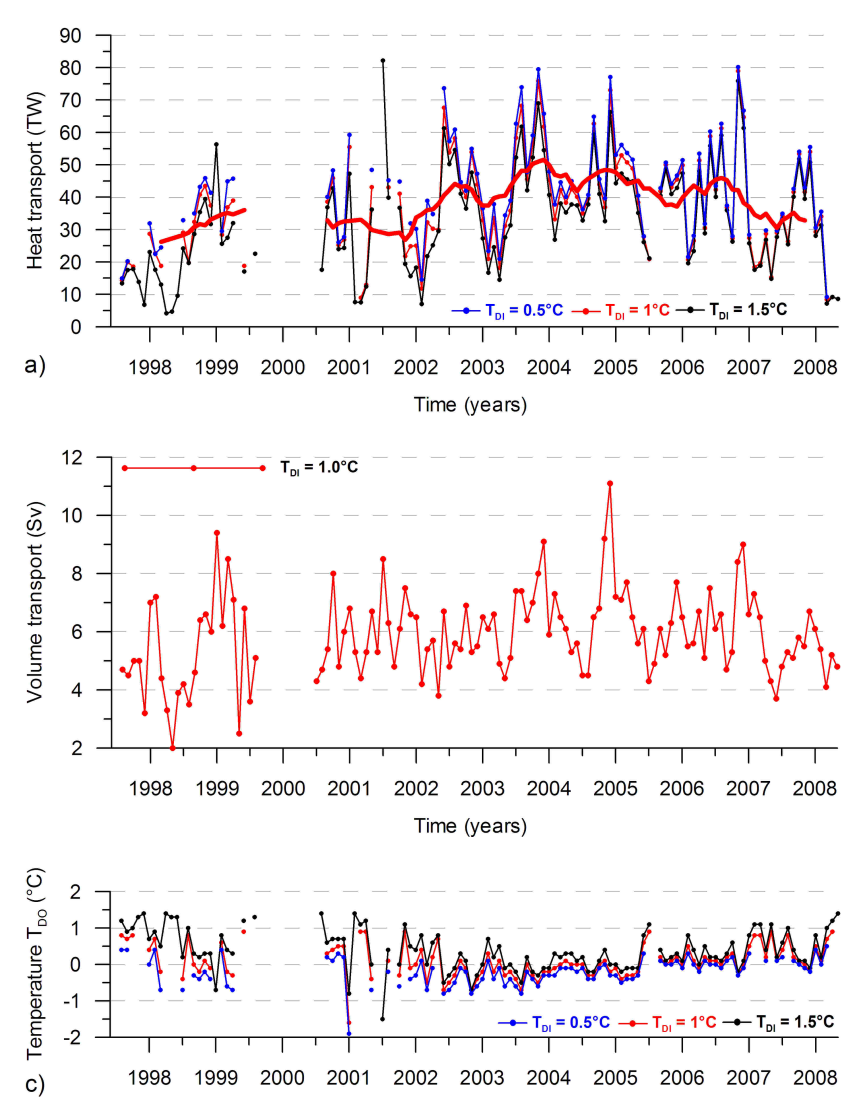

Fig. 3. Time series of heat transport (upper panel) to the Arctic through the WSC water at inflow temperatures higher than $T_{\mathrm{DI}}=0.5^{\circ} \mathrm{C}$ (blue), $1^{\circ} \mathrm{C}$ (red) and $1.5^{\circ} \mathrm{C}$ (black). The dots connected by thin curves are computed from monthly mean values and the bold curve is the yearly running mean. Middle panel: Monthly mean northward volume transport of water warmer than $T_{\mathrm{DI}}=1^{\circ} \mathrm{C}$. Note that this volume transport is less than the bulk number given for the "Fram Strait inflow" in Table 1 which involves also the deep water flow. The lower panel gives the respective limiting outflow temperatures $T_{\mathrm{DO}}$ (see text for explanation). The gap between summers 1999 and 2000 is due to missing moorings in the central Fram Strait.

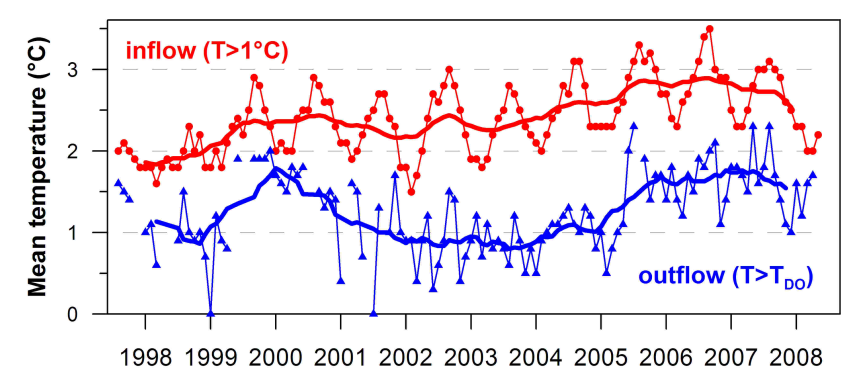

Fig. 4. Time series of the mean temperature of the northward flow (red) of water warmer than $1^{\circ} \mathrm{C}$ and of the respective southward flow (blue). Water flowing southward is warmer than the temperature $T_{\mathrm{DO}}$ given by the red curve in the lower panel of Fig. 3 .

\section{Discussion of inherent uncertainties}

Some aspects of this approach are debatable. The choice of the lower temperature limit for inflow, $T_{\mathrm{DI}}$, is arbitrary. If $T_{\mathrm{DI}}$ is too high, parts of the WSC are excluded, and the heat flux is underestimated as is obvious from comparing the curves for $T_{\mathrm{DI}}=1^{\circ} \mathrm{C}$ and for $T_{\mathrm{DI}}=1.5^{\circ} \mathrm{C}$ in Fig. 3. Ideally $T_{\mathrm{DI}}$ should be chosen low enough that further decrease does not alter the results significantly. However, lowering $T_{\mathrm{DI}}$ below $1^{\circ} \mathrm{C}$ increases the number of months where the computed inflow is larger than the outflow and zero net flow cannot be reached (e.g. $T_{\mathrm{DI}}=0.5^{\circ} \mathrm{C}$ in Fig. 3). This reflects problems with the spatial resolution of the flow. These problems are larger in the first half of the observation period when the mooring number and instrumental coverage was lower than in the second half. Therefore we chose $T_{\mathrm{DI}}=1^{\circ} \mathrm{C}$ as a compromise. The record average difference between the monthly heat transports for $T_{\mathrm{DI}}=1^{\circ} \mathrm{C}$ and for $T_{\mathrm{DI}}=1.5^{\circ} \mathrm{C}$ was $3.5 \mathrm{TW}$ while it was only $2.5 \mathrm{TW}$ between $T_{\mathrm{DI}}=0.5^{\circ} \mathrm{C}$ and $T_{\mathrm{DI}}=1.0^{\circ} \mathrm{C}$, showing shrinking, although not negligible sensitivity.

Obviously the spatial resolution of the measurements remains insufficient - despite the instrumental coverage of this mooring array (16 moorings with 70 instruments) being probably one of the highest in existing ocean observatories. The problem becomes also evident from the variation of the net volume fluxes (Fig. 5). The month-to-month changes of the net volume flow through Fram Strait often reach values of several Sverdrup. If these changes are true, they have either to be compensated by changing flow through other passages or they lead to changes in the water level. However, since all other passages have volume flows in the order of Sverdrup, i.e. of the same magnitude of or even smaller than the monthly changes derived for the Fram Strait flow, compensation of large changes can be doubted. Rudels et al. (2008) discussed that misinterpreting erroneous Fram Strait net transport by flow through other passages would constrain the Arctic fresh water budget in an implausible way. Similar considerations hold for strong variability of the net flow on monthly to annual scales. Both the Canadian Archipelago and the Barents Sea are shallow and only light upper layer water can pass. Flow changes of the order of several Sverdrup over several months would alter the storage of upper layer water masses in a way that would require changes of the production.

If the net flow changes in Fram Strait were compensated by changing Arctic Ocean sea level the amount of water provided by a one-month imbalance of $5 \mathrm{~Sv}$, distributed over the whole Arctic Ocean (approximate area: 10 million $\mathrm{km}^{2}$ ), results in a mean water level change of more than $1 \mathrm{~m}$. If the water is not evenly distributed, local sea level changes would be even larger. This should be visible in tidal gauges.

Another weak point of the presented attempt to derive heat transport is the inherent assumption that no mixing between the Fram Strait and Barents Sea branches takes place. This is certainly not true. Both eddies, likely caused by baroclinic 


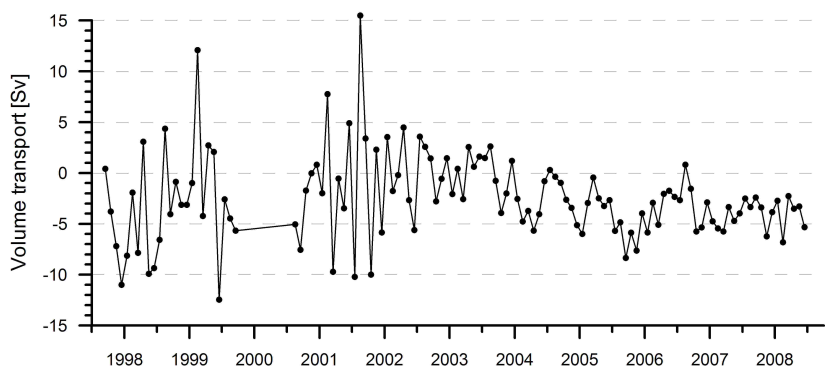

Fig. 5. Monthly averages of total net volume transport through the Fram Strait derived from velocity measurements with moorings.

instability at the confluence of the two branches (Schauer et al., 2002a), as well as interleaving and consecutive doublediffusive fluxes (Rudels et al., 1999) have been shown to exchange water between the branches and to reduce the respective extremes of temperature and salinity. Since Barents Sea water has been cooled to less than $0^{\circ} \mathrm{C}$ when it encounters the Fram Strait branch in the northern Kara Sea our approach might overestimate the heat transport divergence if it captures cold Barents Sea water in the outflow part of the assumed stream tube instead of warmer Fram Strait Water which is returning further west. A proper solution to the problem would be to extend the stream tube concept to involve the Barents Sea inflow. Data of the flow into the western Barents Sea are available (Ingvaldsen et al., 2004) but the heat loss to the atmosphere inside the Barents Sea is much larger than the heat loss of Fram Strait water in the central Arctic and thus would dominate the combined signal. Data of Barents Sea water temperature and flow in the St. Anna Trough are not available; calculation with constant values could, however, provide another approach.

A last severe uncertainty is how much of the WSC inflow exits the Arctic Ocean as sea ice. As has been pointed out before, the sea ice export through Fram Strait of the order $0.1 \mathrm{~Sv}$ corresponds to a latent heat transport of $33 \mathrm{TW}$, which is of the same order as the heat transport in the water passing through Fram Strait. Yet, not all of the $0.1 \mathrm{~Sv}$ ice was formed from water of the WSC; other contributions might be frozen Pacific inflow, Barents Sea inflow and river water. In addition to the missing information of the fraction we have no information on the variability of the total ice transport (for the period considered here only numbers of the areal flow variation are available (Kwok, 2009)), let alone on the variability of the different contributions.

\section{Consequences for observational strategies}

This paper elucidates difficulties inherent in determination of the oceanic heat delivered through advection to the Arctic Ocean. These difficulties point to considerable consequences and tasks for observational strategies some of which cannot be performed with current technology.

First, sections (or openings) have to be identified that are connected by a stream tube and therefore have zero net volume flow, allowing the heat transport divergence to be derived. In the Arctic, the steam tube must include sea ice, not because of the large volume flow but because of the large latent heat. To compute heat transport variability, it has to be taken into account that changes of water or ice transport might be compensated through different sections in different time periods. Consequently, simultaneous observations are needed across those sections and parameters should be measured that allow constraining the stream tube.

Second, because the heat transport term is non-linear, the observations need to be made at sufficient spatial resolution to capture the velocity and temperature structure over the sections. In the Arctic, the internal Rossby Radius, and therefore the lateral scale, is of the order of kilometres. Together with the complex topography in Fram Strait this translates directly into the need for a high number of moorings since currently this is the only way to observe time series with appropriate horizontal resolution. Even with the high instrumental coverage of the mooring array used here, the resolution turned out to be too low to capture the volume flow with sufficient accuracy.

Third, in order to assess what fraction of the heat is released to the surface in the Arctic Ocean vs. what fraction is simply passing and thus available in the Arctic Ocean temporarily, time series have to be long enough to cover the maximum travel time of a parcel which in the case of parcels travelling along the entire Arctic continental slope are decades.

Even if some of these preconditions and requests might be fulfilled the problem of net sea ice export determination is likely to remain unsolved. To date, there is no method available to distinguish from which water mass a particular piece of sea ice was formed. Even less is there any technology to automatically determine the variability of the fraction of sea ice export that was formed e.g. from Atlantic Water entering through Fram Strait.

Given the various causes of uncertainties for the volume transport and for the definition of a stream tube including sea ice, mooring arrays turn out not to be appropriate to derive heat transport. Yet, if designed to capture individual branches at high spatial resolution they could serve very well to obtain mass transports for temperature classes. These can then be used to constrain models or other attempts for determination of temperature transport divergence. 
Acknowledgements. We thank Dirk Olbers, M. Maltrud and one anonymous reviewer for very helpful comments. This work was supported by the European Union MAST III Programme VEINS (Variability of Exchanges in the Northern Seas) contract number MAS3-CT96-0070, the Fifth Framework Programme project ASOF-N (Arctic-Subarctic Ocean Flux Array for European Climate: North), contract number EVK2-CT-200200139, and Sixth Framework Programme project DAMOCLES (Developing Arctic Modelling and Observing Capabilities for Long-term Environment Studies), contract number 018509GOCE.

Edited by: M. Hecht

\section{References}

Cuny, J., Rhines Peter B. , and Kwok, R.: Davis Strait volume, freshwater and heat fluxes, Deep-Sea Res. Pt. I, 52(3), 519-542, 2005.

Fahrbach, E., Meincke, J., Østerhus, S., Rohardt, G., Schauer, U., Tverberg, V., and Verduin, J.: Direct measurements of volume transports through Fram Strait, Polar Res., 20(2), 217-224, 2001.

Hall, M. M. and Bryden, H. L.: Direct estimates and mechanisms of ocean heat transport, Deep-Sea Res. Pt. I, 29, 339-359, 1982.

Ingvaldsen, R. B., Asplin, L., and Loeng, H.: The seasonal cycle in the Atlantic transport to the Barents Sea during the years 19972001, Cont. Shelf Res., 24(9), 1015-1032, 2004.

Karcher, M. J., Gerdes, R., Kauker, F., and Köberle, C.: Arctic warming - Evolution and Spreading of the 1990s warm event in the Nordic Seas and the Arctic Ocean, J. Geophys. Res., 108(C2), 3034, doi:10.1029/2001JC001265, 2003.

Kim, S.-B., Lee, T., and Fukumori, I.: The 1997-1999 abrupt change of the upper ocean temperature in the north central Pacific, Geophys. Res. Lett., 31, L22304, doi:10.1029/2004GL021142, 2004.

Kwok, R.: Outflow of Arctic sea ice into the Greenland and Barents seas: 1979-2007, J. Climate, 22, 2438-2457, doi:10.1175/2008JCLI2819.1, 2009.

Lee, T., Fukumori, I., and Tang , B.: Temperature Advection: Internal versus External Processes, J. Phys. Oceanogr., 34(8), 19361944, 2004.

Maslowski, W., Marble, D., Walczowski, W., Schauer, U., Clement, J. L., and Semtner, A. J.: On climatological mass, heat, and salt transports through the Barents Sea and Fram Strait from a panArctic coupled ice-ocean model simulation, J. Geophys. Res., 109(3), C03032, 1-16, 2004.

Montgomery, R. B.: Comments on "Seasonal variability of the Florida Current," by Niiler and Richardson, J. Mar. Res., 32, 533-535, 1974.
Polyakov, I. V., Beszczynska, A., Carmack, E. C. , Dmitrenko, I. A., Fahrbach, E., Frolov, I. E., Gerdes, R., Hansen, E., Holfort, J., Ivanov, V. V., Johnson, M. A., Karcher, M., Kauker, F., Morison, J., Orvik, K. A., Schauer, U., Simmons, H. L., Skagseth, Ř., Sokolov, V. T., Steele, M., Timokhov, L. A., Walsh, D., and Walsh, J. E.: One more step toward a warmer Arctic, Geophys. Res. Lett., 32(17), L17605, doi:10.1029/2005GL023740, 2005.

Rudels, B., Jones, E. P., Anderson, L. G., and Kattner, G.: On the intermediate depth waters of the Arctic Ocean, in: The Polar Oceans and Their Role in Shaping the Global Environment, AGU, Washington, D.C., 33-46, 1994.

Rudels, B., Björk, G., Muench, R. D., and Schauer, U.: Doublediffusive layering in the Eurasian Basin of the Arctic Ocean, J. Marine Syst., 21(1-4), 3-27, 1999.

Rudels, B., Marnela, M., and Eriksson, P.: Constraints on Estimating Mass, Heat and Freshwater transports in the Arctic Ocean: an Exercise, in: Arctic-Subarctic Ocean Fluxes: Defining the Role of the Northern Seas in Climate, Springer Science + Business Media B.V., Dordrecht, 315-341, 2008.

Schauer, U., Rudels, B., Jones, E. P., Anderson, L. G., Muench, R. D., Björk, G., Swift, J. H., Ivanov, V., and Larsson, A.-M.: Confluence and redistribution of Atlantic water in the Nansen, Amundsen and Makarov basins, Ann. Geophys., 20, 257-273, 2002a, http://www.ann-geophys.net/20/257/2002/.

Schauer, U., Loeng, H., Rudels, B., Ozhigin, V., and Dieck, W.: Atlantic Water flow through the Barents and Kara Seas, DeepSea Res. Pt. I, 49(12), 2281-2298, 2002b.

Schauer, U., Fahrbach, E., Osterhus, S., and Rohardt, G.: Arctic warming through the Fram Strait: Oceanic heat transport from 3 years of measurements, J. Geophys. Res., 109, C06026, doi:10.1029/2003JC001823, 2004.

Schauer, U., Beszczynska-Möller, A., Walczowski, W., Fahrbach, E., Piechura, J., and Hansen, E.: Variation of Measured Heat Flow Through the Fram Strait Between 1997 and 2006, in: Arctic-Subarctic Ocean Fluxes: Defining the Role of the Northern Seas in Climate, Springer Science + Business Media B.V., Dordrecht, 65-85, 2008.

Vinje, T.: Fram Strait ice fluxes and atmospheric circulation: 1950 2000, J. Climate, 14(16), 3508-3517, 2001.

Walczowski, W., Piechura, J., Osinski, R., and Wieczorek, P.: The West Spitsbergen Current volume and heat transport from synoptic observations in summer, Deep-Sea Res. Pt. I, 52, 1374-1931, 2005.

Woodgate, R. A., Aagaard, K., and Weingartner, T. J.: Interannual changes in the Bering Strait fluxes of volume, heat and freshwater between 1991 and 2004, Geophys. Res. Lett., 33(L15609), doi:10.1029/2006GL026931, 2006. 